\title{
Romanian choral music in the interwar period
}

\section{Dorin-Mircea SIMIONESCU*}

Abstract: The spiritual and artistic climate of the musical life in Romania during the interwar period was shaped by the influences of the European musical culture, namely French, Austrian and German. In the first half of the twentieth century, most of our composers, in their quest for a national language, focused on different European styles, which they fused within their own culture. Among the most important representatives of this period were: D. G. Kiriac, Gh. Cucu, Sabin Dragoi, Gh. Danga, T. Popovici, Ion Vidu, Paul Constantinescu and others. The interwar generation was a strong advocate of a specific Romanian music. The composers of this period achieved a synthesis of the national with the universal in the musical language, and brought the Romanian cultivated creation to the technical and artistic level of world Postromantic music, at a time when the expressive capacity of music was increasingly neglected.

Keywords: choral music, interwar music, Romanian composers, Byzantine music, culture, art, music.

In their struggle for the creation of a Romanian cultivated music, the musicians of the interwar period had to face great obstacles due to the actions of denationalization conducted by the

* PhD., Lecturer, at the Faculty of Orthodox Theology, "1-st December 1918" University in Alba Iulia, Romania. 
totalitarian empires. The collapse of these empires, from which so many peoples in Eastern Europe gained their freedom, made the Austrian and German musical cultures temporarily diminish their influence, unlike the French one. These influences of the old musical cultures, as well as the new currents that emerged within them around and immediately after World War I, shaped the spiritual and artistic climate of the interwar Romanian musical life. The role of musical cultures in the neighbouring countries was also considerable, where Bartók, Janaček, Szymanowski offered valuable experiments in the process of developing national music schools, a process under the conditions of the new musical languages related to the currents of the time.

The realization of the Romanian specific language and reaching a stage of professionalism are due to the disciples of Castaldi: D. Cuclin, I. N. Nottara, T. Rogalski, G. Enacovici, A. Alessandrescu, C. Georgescu, M. Jora, M. Andricu. Under the influence of the education received in Germany and especially in Paris, these composers exhibited a dualism in terms of musical language. Using a universal language in their creations, some composers sought to imprint a national colour only in the works with title or program, referring to Romanian life and spirituality. Instead, the national composers - S. Drăgoi, M. Negrea, Al. Zirra, M. Andricu - produced musical creations based on folkloric quotations or on their own themes written in folk style.

The interwar generation firmly militated for the specific Romanian music through their creations and the active presence in the musical life. Enescu was the mentor of Romanian musical life, a model and a catalyst for the other composers. He realized the synthesis of the national with the universal in the musical language and brought the Romanian cultivated creation to the technical and artistic level of worldwide Postromantic music, in an age where the tendency to refuse music its expressive capacity was growing stronger. 
After the achievement of Greater Romania in 1918, our culture developed in all its domains. The Romanian musical culture, nourished in the previous century by Romantic music and the echoes of a late Classicism, assimilated stylistic data from several currents. In the interwar period, foreign influences arrived from three directions: France, Germany and Italy. Those who studied in Paris display the influence of the Impressionist and Neoclassical styles with academic tinges, supported by d'Indy, who sustained the cult for Bach, Beethoven, Wagner, Franck. Stimulated by d'Indy our musicians searched for national specificity by employing folk-derived formulas. Those who studied in Germany gained a severe polyphonic discipline, a solid technical language, a greater density of expression and sobriety in colouring. The influence of the Italian Verism and Neoclassicism was rather lower.

One of the most important representatives of this period was Dumitru Georgescu Kiriac (1866-1928), a personality that contributed to choral musical creation, chamber music, theatre music, choral adaptations and arrangements in folklore, musicology but especially in music education. Dumitru Georgescu Kiriac had the merit of opening new ways of creation, interpretation and teaching, which enable us to assert that this great musician and teacher was a creator of national school.

Dumitru Georgescu Kiriac remains a classic of Romanian music without which composers such as Gheorghe Dumitrescu, Martian Negrea, Mihail Jora, Paul Constantinescu, Mihail Andricu and others who in turn became teachers of a new generation would not have emerged. When Dumitru Georgescu Kiriac began to collect folklore in the Romanian musical field in 1910 it led to a turning point, as this great folklorist chose the rural environment, extracting from there the most authentic gems of folk creation. To his folklore collections were added those of 
Anton Pann, Theodor Burada, Dimitrie Vulpian, Ion Andrei Wachmann, and constituted the true source of his creation.

After spending five years in Paris at Schola Cantorum ${ }^{1}$, he returned to the country where he developed his true artistic sense, correctly adapting the classical harmony to the potential of folk songs of modal structure. Convinced that text music is closer to the souls of music lovers, Dumitru Georgescu Kiriac composed many vocal songs in folk style but also inspired choral works for equal voices.

Dumitru Georgescu Kiriac started his musical studies at the "Ciprian Porumbescu" Conservatory in Bucharest, having Eduard Wachmann (harmony and composition), Gheorghe Bratianu (theory and solfege) as professors. After completing his studies at the Conservatory, he went to the capital of France, Paris, where he furthered his musical studies with professors such as Bourgault-Ducoudray and Vincent d'Indy, and afterwards returned to the Conservatory in Bucharest, where he was appointed professor of theory and solfege.

D. G. Kiriac was the composer who fought with unwavering confidence in the future of our music. In Paris he studied with V. d'Indy, a teacher whose guidance shaped many Romanian musicians. Indy directed these students to research the musical values of the Romanian people and of the Byzantine chant. Most musicians preceding Kiriac had sporadically adapted Western art to the Romanian song. Like Musicescu, Kiriac sought out the harmonies specific to our folk song, writing numerous choruses for young people and adults. In a letter to d'Indy, Kiriac confessed his artistic creed: "You made me love the flowers of the field, the small sincere and original musical inspirations of this Latin people in the

${ }^{1}$ Superior Music School founded by Charles Bordes along with Vincent d Indy in 1894 in Paris. The basic disciplines were: Gregorian singing, Renaissance polyphony, organ and composition. 
Orient. I went far into the mountains and the plains to collect the 'green leaves' in which the pains and joys of an entire nation are gathered. I dressed them in the new garland of humankind by giving Romanian songs for the young and the elder"'.

Pieces such as: Secerişul [The Harvest], Morarul [The Miller], Fata şi cucul [The Girl and the Cuckoo Bird], Am umblat pădurile [I Rambled Through the Woods], Hi, hai, murgule hai [Let's Go, Roan] and other choral works delighted and still delight generations of listeners. His choir creations, small musical gems, opened new paths in Romanian music.

By studying the Byzantine music, which had a strong influence on our folklore, he also wrote valuable religious compositions for choir such as the extensive Psaltic Liturgy, using the Byzantine melos, which enriched the heritage of the European musical culture.

The "Carmen" Choral Society, whose main coordinator and founder was D. G. Kiriac, contributed to raising the level of Romanian musical life both by promoting the local creations and by presenting the world repertoire. Near his death, he wrote to Ion Chirescu about the thesis of capitalizing on folk creation: "The idea succeeded, it only remains that you, the descendants, go forward on this path, because I trust that this is the only way we may leave our own traces in the world"'3. In the Romanian music, the modal melos, the particularly attractive rhythms, both through their permanent variation and the suggestive asymmetry, are the profound expression through which the composers achieved many creations inspired by the melancholic songs and the dazzling dances of the folk. This tremendous treasure, our great folklore cannot be neglected, even though a small circle of

2 D. G. Kiriac, Pagini de corespondență, Bucharest: Muzicală Publishing House, 1974, p. 112.

${ }^{3}$ Ibid. 
musicologists consider themselves "bored" by it and show their lack of confidence in the important role that it may play in the cultivated art. The role of the composer is to assimilate the folklore, having to take into account all the technical conquests of the compositional art of his time, and use through a carefully chosen selection the ones that characterize it, in order to create a rich content of ideas and feelings, realized in a new form, at a high artistic level.

Starting from these considerations, one may state that the work of Gheorghe Cucu (1882-1932) represents another important moment in the development of Romanian choral music. His melodious music, full of bright colours, conceived in a widely accessible style, appears to us as an art impregnated with vitality and energy. The creation of Gheorghe Cucu is characterized by an expression of remarkable authenticity, an original style with distinctive features, and a work characterized by firmness.

A graduate of the Bucharest Conservatory, a successful composer included in the repertoire of the "Carmen" Society, endowed singer and valuable conductor of the Brezoianu church choir in Bucharest, Gheorghe Cucu had the opportunity to improve his knowledge at Schola Cantorum from 1908 to 1911. The complex personality of Vincent d'Indy had a positive role in his artistic formation. During this period he composed a song on Ronsard's verses from the famous poetry Ode a Cassandre, a romance on the poetry of Jean Richepin and another romance, Romanian, on a poem by Hîrjau, translated by Bachelin into French.

The musicologist Riegler-Dinu, in his study on Gheorghe Cucu in Paris, analyzing the song Ode a Cassandre, asserted: "The style of the young Romanian composer is surprisingly adequate to the poetry". Significant are also the indications of the great master Vincent d'Indy - "d'excellentes choses mais parfois trop de subtilites rythmiques". Although at that time in Paris the 
genre of romance was fashionable, Gheorghe Cucu did not follow in this direction. He learned from Vincent d'Indy the compositional technique of the great classics, especially in terms of form and harmony. In 1914, he returned to the country, mastering a true compositional technique, dedicating himself to the collection and choir arrangement of the folk songs, enriching at the same time the choral repertoire with original compositions written in the spirit of our folklore. The choral pieces he wrote in the 20 years of creative activity are imposing not so much by their number but by their special artistic quality.

His choral works include: carols on two-three voices, generally intended for school children; pieces for male and mixed choirs, in which the folk song is subject to some development; more developed original compositions that often use forms of instrumental music, such as the rondo, which lays at the basis of one of his most important choral works, Haz de necaz [Laugh at Sorrow].

From the category of mixed chorus works, there are the songs: Frumosul vine pe apa [The Beautiful Comes on Water] (on folk verses), Craciunul [Christmas] (text by IU Soricu), Luceferii [The Morning Stars] (verses by Petre Dulfu), Mincinosul [The Liar] (verses by IU Soricu), Greierul [The Cricket] by IU Soricu), Mânia [The Anger] (on folk text), etc.

A special place in his works of secular character is held by the few songs for voice or voice and piano, some on Romanian verses such as: Cântecul codrului [The Song of the Woods] (verses by Stefan Octavian Iosif), Cântec [Song] (text by Calin Moldoveanu), Blestemul [The Curse] (on folk verses) and others on verses by French poets; the melody of the latter differs, in structure, essentially from that of the songs on Romanian texts, but especially the melody of his choruses stands as his own invention. 
As valuable as the secular is his religious creation for choir, consisting, on the one hand, of adaptaing authentic church songs, and on the other, from creations entirely his own, among which the most important one is the Liturgy for mixed choir. Due to the expressive force, the originality of the melodic invention, which is a personal adaptation of the psaltic chant, Gheorghe Cucu's Liturgy can be considered as the climax of the entire Romanian creation of this kind. Given the excellent contrapunctic writing of Gheorghe Cucu's sacred works, it is necessary to compare his polyphonic style with that of Dumitru Georgescu Kiriac.

While the Psaltic Liturgy of Dumitru Georgescu Kiriac and his other works based on church chants, as well as those of folk songs are characterized by a contrapuntal style in which the leading of voices is determined by certain harmonic considerations, Gheorghe Cucu's polyphonic writing is more akin to that of the masters of the vocal polyphony of the Renaissance. Thus, as in their music, in Gheorghe Cucu's works the voices are based on a melodic primal impulse, but in this case, between the overlapping voices there are well-defined vertical relations that have not been established in a transcendental manner, but they are the secondary result of voice leading. This way of conceiving polyphony is vividly characterized by Gheorghe Cucu himself by the guidance he gave to his disciples saying: "Do not look for pre-established chords, but coincidences must be harmonious"4.

The differences between the polyphonic writing of the two composers and the different way in which they treat especially the folk songs are due to their differences in the attitude towards folklore. While Dumitru Georgescu Kiriac manifested a preference for the folk songs of archaic modal structure, considering modalism as a major sign of folk authenticity and

4 Zeno Vancea, Creația muzicală românească, sec. XIX-XX, Bucharest: Muzicală Publishing House, 1969, p. 187. 
emphasizing the modal features of the songs through the preponderance of the vertical-harmonic specificity, Gheorghe Cucu chose especially "modern" type folk songs, whose melodies are based on a major or minor key.

Being used to consider that polyphony is more suitable for the treatment of modal melodies - which, in their structure, contain only vague indications of harmony that is latently included in the melody - and the chord progressions more suitable for those type of melodies conceived in major and minor key ranges, it would seem that there is a contradiction between the way the two composers treat the folk song. Gheorghe Cucu's polyphony originates from his own melodic sense, regardless of the structure of the folk song or of the chant. This melodic preference over a harmonic writing is also evidenced by the simplicity, the lack of variety in harmony, which has often been reproached by some choir conductors, more accustomed to the Western harmonic embellishment of folk songs, who consequently neglected the works of Gheorghe Cucu. At any rate, the solutions given by the two composers represent equally valuable contributions, proving the multiple possibilities of approaching the folk song. This renders unnecessary the question posed by some critics of the creation of Dumitru Georgescu Kiriac and Gheoghe $\mathrm{Cucu}$, wondering which of the two composers is more important. Even if we admit that the works of Gheoghe $\mathrm{Cucu}$ represent a crowning of the creative efforts of his predecessor, historically, Dumitru Georgescu Kiriac has the merit of being the initiator, the artist of a wider cultural sweep, who, understanding the value of folklore, gave an decisive impetus in the promotion of a cultivated art, having a national character that springs from the valorization of the characteristics of folk music.

After the Great War, Sabin Drăgoi (1894-1968, born in Sălişte in Banat) worked for a while in Iaşi with Zirra (19191920), adopting with conviction his precepts, for which he 
himself had been prepared by other Transylvanian predecessors. He continued his studies at the Conservatory of Cluj with Augustin Bena and Hermann Klee, and afterwards went to Prague where he continued his composition studies with the composer Viteslav Novak, whose aesthetic principles coincided with those of Zirra.

Drăgoi imposed himself in Romanian music through the novelty of the pure Romanian style, especially with Divertisment rustic [Rustic Entertainment] (1928), about which Enescu firmly stated: "the sun of Romanian music has emerged" and, of course, awarded him the "G. Enescu" prize. Divertisment rustic is built entirely on folkloric quotations, supported by modal harmonies in its five parts: Colindă (O, ce veste minunată) [Carol], Doină [Doina], Bocet [Lament], Dans [Dance], Cântec de nuntă [Wedding song]. At the same time, Drăgoi wrote the most relevant Romanian compositions: Năpasta [The Misfortune] (1927), the comic opera Kir Ianulea (1937), the opera-oratorio Constantin Brâncoveanu (1929). Along with the historical opera Horia (1943) and the comic opera Păcală (1956), we also mention for the symphonic genre Divertisment sacru [Sacred Entertainment] (1933), Rapsodia bănăţeană [Banat Rhapsody] (1942), Concertul pentru pian şi orchestră [Concert for Piano and Orchestra] (1941).

A very important contribution was made by Dragoi in the continuation of the Banat choral tradition, established by I. Vidu. Like his Răsunetele [Echoes], the choirs of Drăgoi, Idilă bihoreană [Bihar Idyll], Trandafir de pe răzoare [The Rose from Flower-Beds], Banățeana [Banat Dance], became classical pieces, customary to the choral repertoire, defining for the appropriation of the traditional Romanian choral style.

5 Petre Brâncuși, Istoria muzicii românești, Bucharest: Muzicală Publishing House, 1969, p. 293. 
Liturghia în Fa major [Liturgy in F Major] (1937) and Recviemul românesc [Romanian Requiem] (1943) are considered in the literature as works which contribute to the stylistic polychromy of the repertoire of the Orthodox Church.

For the current repertoire of the Romanian salon, Drăgoi contributed greatly to the realization of an instrumental repertoire with: 12 Miniaturi pentru pian [12 Piano Miniatures] (1968), Suita de dansuri populare [Folk Dances Suite] (1923), Mica suită pentru pian [Little Piano Suite] (1955), Colinde pentru pian [Carols for Piano] (1957), Sonata pentru vioară şi pian [Violin and Piano Sonata] (1949). Often sung and appreciated were also his lieder, including Doine [Doinas], Cântece populare [Folk Songs], Anii tineri [The Youth Years] and the much appreciated lied Crizanteme [Chrysanthemums].

Gheorghe Danga (1905-1959) dedicated his entire artistic activity to Romanian choral music. As a conductor, he performed in countless concerts popular songs, folklore arrangements and choral poems. He created a considerable number of vocal compositions, especially for amateur ensembles, designed in the most authentic folk spirit, simple, easily sung and widely accessible. His style is harmonic and diatonic, closer to the Western major-minor than to the issues of the modal musical discourse, having a clear and symmetrical rhythm, with regular metric accents. Gheorghe Danga's choral music did not surpass the stage of folkloric adaptation, yet due to the earnestness of the vocal expression and neat vocal writing, it is sung with pleasure and has a moving quality. Several titles of choral works: $\hat{I} n$ poeniţă lângă plopi; Sârba-n căruţă; Di, di, di, murgule, di; Ca la Breaza; Zamfira; Sârba pe loc, Ca pre Împăratul; Unule născut.

Timotei Popovici (1870-1950) priest, educator and outstanding composer, wrote numerous secular and religious 
compositions, for children's choir, school choirs, choirs for three voices and male choirs.

In 1901 he was elected honorary member of the "Carmen" Musical Society in Bucharest.

The lack of necessary coursebooks led Timotei Popovici to edit the Music Dictionary, as well as several other papers of utmost importance for the theoretical and practical study of music. The Music Dictionary was the first complete Romanian music dictionary.

On 1-st of December 1918 he participated in the Great Unification of Alba Iulia, where he conducted the piece Sosit-a ceasul liberării [The Hour of Liberation Has Arrived], his ad-hoc creation. Between the years 1918-1919 he was a member of the Romanian National Guard, founded in Transylvania after the collapse of the Austro-Hungarian monarchy in the autumn of 1918.

In 1920 he was one of the founding members of the Society of Romanian Composers.

For most of his life Popovici led church and school choirs, amateur ensembles. He remained for several decades the choir conductor of the Metropolitan Cathedral in Sibiu, until 1945. He trained the conductors of many folk musical ensembles. He participated in 1924 in a national tour with the choir of the "Andrei Şaguna" Normal School choir, as a conductor, achieving a remarkable success. Also in 1924 he published the choral poem Regele muntilor [King of the Mountains] (inspired by the life of the national hero Avram Iancu), which would be one of his most valuable creations.

Throughout his life, as a composer, Timotei Popovici composed secular and religious choruses, for mixed ensembles or on equal voices, for children, men and women, and instrumental music for fanfare orchestra. Among his most important compositions are two Liturgies, the choral piece La oglind $\breve{a}$ [By 
the Mirror], the poem Avram Iancu and Cântece naţionale [National Songs].

In 1936 he retired, but without completely interrupting his activity, so that in 1946 he founded the Sibiu Music Conservatory (nowadays the Folk Art School). The Conservatory in Sibiu beared his name for some time.

Timotei Popovici also took care of the republication of D. Cuntan's book, Cântările bisericești după melodiile celor opt glasuri [The Church Chants According to the Melodies of the Eight Modes].

Some of the most famous Romanian Christmas carols (Trei păstori [Three Shepherds], Astăzi s-a născut Cristos [Today Christ Was Born], Florile dalbe [White Flowers]) were arranged by Timotei Popovici. One of the most famous songs taught nowadays in primary school, La oglindă [By the Mirror], was set to music by Timotei Popovici.

Ion Vidu (1863-1931), composer and conductor, was born on December 17, 1863, in Mânerău, in Arad county. He studied at the Conservatory of Arad (1880-1881), Caransebeș (1885), and afterwards attended the courses of harmony and conducting in Iasi with the great composer Gavriil Muzicescu. He taught music in Arad and the surrounding area, between 1881-1883 and 1884-1888, as well as in Lugoj, at the Confessional School, "Coriolan Brediceanu" High School, ending his teaching career as a general music inspector for the normal schools in the country. Besides the teaching chair, he conducted a vast and prodigious creative activity, conducting the "Reuniunii române de cântări și muzică" [Romanian Reunion of Songs and Music] in Lugoj, a publicist and animator.

The area of its creation is vast: opera and piano compositions, vocal and symphonic music, but it ishe is most remarkable through the choral works: Din șezătoare [At the Bee], Ana Lugojana, Răsunetul Ardealului [The Echo of 
Transylvania], Preste deal, [Over the Hill], Negruța [The Little Black One], Moartea lui Mihai eroul [The Death of Michael the Hero], Ștefan și Dunărea [Stephen and the Danube], which are anthological pieces of Romanian choral music; they are part of the classical compositional background, real touchstones for artistic performance choruses. Between the choir creations of Ion Vidu, a special place is held by the religious choral music for three equal voices, male choir and mixed choir, comprising a vast repertoire: liturgies, funeral songs, communion songs, troparia, axions, hymns and carols - such a necessary repertoire, especially in Banat, where the church choir movement at that time was increasingly growing, unlike many other Romanian provinces. Ion Vidu composed this religious music 'with proper piety' and deposited it "on the altar of the Church of the Romanian people, to the glory of God ... whose grace sustained the flame of the everlasting faith in the heart of this people". Ion Vidu's religious musical creation is based on the traditional church chant in Banat, some of which are among the most accomplished in the Orthodox repertoire, such as Mântuire [Salvation].

The choir conducted by him became one of the most famous choirs of the time and brought the fame of Lugoj over the Carpathians. For example, at the 1906 Universal Exhibition in Bucharest, "Vidu' Choir' made fare to the Romanian Arenas singing "Lugojana" or "Sus opinca"

After the Unification of 1918, he was appointed by the Governing Council a music teacher at Coriolan Brediceanu High School in Lugoj. On 1 April 1926 he was appointed by the Ministry of Instruction as a general music inspector over the entire country.

Ion Vidu wrote opera scores, vocal concerted pieces, music for piano, but he was particularly noted due to his choral works.

${ }^{6}$ Zeno Vancea, op. cit., p. 146. 
He wrote over 160 choir compositions. The most important works are "Lugojana," "Ana Lugojana," "Eroi au fost " [Heroes They Were], "Pui de lei" [Lion Cubs], " Răsunetul Ardealului" [The Echo of Transylvania], "Din şezătoare" [At the Bee], "Negruta" [The Little Black One], "Auzi valea" ["Listen to the Valley], "Peste deal" [Over the Hill], "Moartea lui Mihai eroul" [The Death of Michael the Hero], "Ştefan şi Dunărea" [Stephen and the Danube], "Pâc-pâc-pâc," "Coasa" [The Scythe], etc. Some of them became anthological parts of Romanian choral music. Ion Vidu unravelled the musical sentimentality of the Banat soul and transposed it into his works.

Ioan Vidu was the founder and president of the Romanian Choir and Fanfare Association in Banat (1922), which included over 200 choirs and 60 fanfares in the Romanian Banat, as well as about 100 from the Serbian Banat. In 1921, on the occasion of the $40^{\text {th }}$ anniversary of musical activity, the "Ion Vidu" foundation was set up to help talented students in music. He helped choir conductors by organizing training courses for them.

The merits of this great composer were recognized and he was awarded the First Class Bene merenti; Reward for church and education work; The Order of the Crown in the Commander class; The Order of the Star of Romania in Officer rank; at his death he was given the Order of King Ferdinand I, the highest distinction given to the great Romanian fighters for the unity of the people.

In the twentieth century, most of our composers, convinced by the necessity of a national language, focused on different European styles, realizing specific blends within the Romanian culture. Influenced through his education by the Italian neoclassicism, with a imposing majesty, Sigismund Toduţă (19081991) appears to us as a consistent follower of the national idiom of language, but also of the forms of the Baroque, analyzed by him in three pertinent and valuable volumes dedicated to Bach's 
work on the phenomenon of music based on the statue of the Baroque and its pontiff J. S. Bach.

Another prominent figure of Romanian music was Paul Constantinescu (1909-1963), remarkable through his own style with many innovative features. Born in Ploiesti, where he began his musical education, he became the pupil of M. Jora, D. Cuclin, C. Brăiloiu, G. Breazul, St. Popescu and Franz Schmidt and Joseph Marx at the "Academy" in Berlin. Through the guidance of his professors, but also by studying the works of our forefathers, P. Constantinescu proposed the creation of a vibrant and colourful musical language derived from the folk melos. In most of his works he used his own themes or collected ones, written in folk style and exploited with original expressive means. Master of an outstanding compositional craft, he wrote in the most varied forms, penetrated by a spirit of synthesis and his own architectural vision. By proposing to capitalize on the folk treasure in symphonic music, he refreshed the Romanian symphonic musical language with sharp rhythm and brilliant orchestration.

He exploited the archaic elements present in laments, carols, ballads and in church singing, as well as fiddler or salon music. In terms of orchestration, using the style of folk instruments, he contributed together with Negrea, Rogalski and Jora to the creation of the modern orchestra, specific to the Romanian musical school. By his link with folk songs and dances, he defined not only the vocabulary, but also the synthesis of language, the conciseness and proportion of structures being balanced components of his musical thinking.

Apart from the use of Byzantine sources in the two Studies in Byzantine Style (1929), the Variatiunile libere asupra unei melodii bizantine din secolul al XIII-lea pentru violoncel şi orchestră [Free Variations on a $13^{\text {th }}$ Century Byzantine Chant for Cello and Orchestra], Trio bizantin pentru coarde [Byzantine 
Trio for Strings], Sonatina bizantină pentru violoncel solo [Byzantine Sonata for Cello Solo] (1940), Constantinescu wrote Liturghia în stil psaltic [Liturgy in Psaltic Style] (1935), Oratoriul bizantin de Crăciun [Byzantine Christmas Oratorio] (1947) and Oratoriul de Paşti [Easter Oratorio], towards the end of his life, Triplul concert pentru pian, vioară şi violoncel şi orchestră [Triple Concerto for Piano, Violin and Cello] (1963), works contributing to the valorisation of the psaltic melos in a modern technique. Oratoriul Naşterii Domnului [Oratorio of the Nativity] is conceived as a luminous hymn of glory of the "Saviour's Birth," and Invierea Domnului [Resurrection of the Lord] as a deeply dramatic drama. Both oratorios are impressive artistic achievements, made by symphonizing the old psaltic chants and his own in Byzantine style, with complex tonal planes, dynamic recitatives, modal harmonies and a colourful orchestral language. It is the great merit of the composer Constantinescu to be sincere in his creation and to have the ability to achieve a compelling music.

At the turn of the twentieth century, when all the musicians made considerable efforts to build a new ambience in the Romanian musical activity, the eyes were unanimously directed towards the West, in this case to Germany and France. Even the Russian composers, who already had a notorious culture with serious adherents abroad, kept in touch with the great European masters. In our country, G. Ştephănescu, C. Dimitrescu, I. and Ed. Wachmann, Gh. Dima, Ed. Caudella, G. Musicescu, E. Mezzetti prepared the ground for the junction of our music with that of the West. Two main springs were configured, on the one hand Paris, and on the other, Vienna, Berlin and Leipzig. If the German school imprinted the solidity of the construction, an architectural order, the French one complements it with a more aerated, free and colourful expression. For the Romanian school, the ideal was that the young people, abroad for completing their 
music education, would go through both schools, which in fact took place in some cases.

\section{References}

1. Dicţionar de mari muzicieni, Bucharest: Univers Enciclopedic Publishing House, 2000.

2. Avram, Florea, Creaţia corală românească din Banat. Perioada interbelică. Între prelucrarea sursei folclorice şi bizantine şi creaţia originală Timişoara: Mirton Publishing House, 2004.

3. Bălan, George, Mesajul universal al muzicii româneşti, Bucharest: Muzicală Publishing House, 1996.

4. Bentoiu, Pascal, Trăsături ale armoniei în muzica populară, Bucharest: Muzicală Publishiung House, 1964.

5. Brâncuși, Petre, Istoria muzicii româneşti, Bucharest: Muzicală Publishing House, 1969.

6. Breazul, George, D. G. Kiriac, Edited by Titus Moisescu, Bucharest: Muzicală Publishing House, 1966.

7. Cosma, Octavian Lazăr, Hronicul muzicii româneşti, vol. VII, Bucharest: Muzicală Publishing House, 1976.

8. Georgescu-Kiriac, Dumitru, Pagini de corespondenţă, Bucharest: Muzicală Publishing House, 1974.

9. Grăjdian, Vasile, Teologia cântării liturgice în Biserica Ortodoxă (aspecte de identitate a cântării liturgice ortodoxe), Sibiu: University of "Lucian Blaga" Publishing House, 2000.

10. Vancea, Zeno, Creaţia muzicală românească, sec. XIX-XX, Bucharest: Muzicală Publishing House, 1969. 